Закцентовано увагу на тому, що зазначені художньо-освітні заклади дали можливість розкрити талант багатьох українських митців та втілити педагогічні ідеї провідних учителів-художників Слобідської України.

Доведено, що окреслена проблема потребує ретельного вивчення історії розвитку художньої освіти Слобідської України в таких галузях наукового пізнання, як історія культури, історія педагогіки, історія мистецтва.

Ключові слова: Слобожанщина, педагоги-художники, українські рисувальні школи, Петербурзька Імператорська академія мистецтв.

удк 37.02:378.4(477-81)

Аліна Сбруєва

Сумський державний педагогічний університет імені A. С. Макаренка ORCID ID 0000-0002-1910-0138

Марина Бойченко

Сумський державний педагогічний університет імені А. С. Макаренка ORCID ID 0000-0002-0543-8832

Ольга Чашечнікова ORCID ID 0000-0003-1101-5534

Сумський державний педагогічний університет імені А. С. Макаренка DOI 10.24139/2312-5993/2020.02/311-326

\title{
СТАНОВЛЕННЯ КОНЦЕПЦІЙ І ТЕХНОЛОГІЙ ЕВРИСТИЧНОЇ ОСВІТИ В ДОСЛІДЖЕННЯХ УКРАЇНСЬКИХ НАУКОВЦІВ
}

Статтю присвячено аналітичному огляду й узагальненню результатів досліджень українських науковців, спрямованих на виявлення основних джерел, тенденцій і проблем становлення концепцій і технологій евристичної освіти (EO) в зарубіжній і вітчизняній педагогічній науці. Установлено три джерела й одночасно три складники евристичної освіти: сократівський (евристичний) діалог; концепція творчої самореалізації особистості; методологічні й технологічні основи творчої діяльності. Виявлено, що EO та їі складники мають тенденції до постійного вдосконалення, модернізації і одночасно до ускладнення змісту, способів освоєння та використання.

Ключові слова: евристична освіта, концепції і технології, евристичний діалог, творча самореалізація особистості, творча діяльність, зарубіжна і вітчизняна педагогічна наука, етапи, тенденції розвитку.

Постановка проблеми. Стратегія й завдання освіти сучасних громадян України ґрунтовно визначені в Національній доктрині розвитку освіти (2002), Законах України «Про вищу освіту» (2014), «Про освіту» (2016), «Про загальну середню освіту» (2020), уточнені в Концепції «Нова українська школа» (2016), інших державних і відомчих документах, підтверджені результатами досліджень багатьох науковців. Реалізація окресленої стратегії розвитку національної освіти пов'язана з відмовою від застарілої, репродуктивної, антидіалогічної системи навчання й виховання і побудовою інноваційних моделей і технологій освіти, коли педагог не передає готові знання, а співпрацює зі школярами та студентами, включає їх у самостійну пошукову, 
конструктивну й дослідницьку діяльність. Перехід закладів вищої і середньої освіти до інноваційної системи освіти - процес суперечливий і довготривалий, він ускладнюється багатьма факторами: дефіцитом компетентних людських ресурсів - освітніх, наукових, управлінських, тривалим розробленням i застосуванням інноваційних концепцій та технологій, відсутністю дієвих і потужних освітніх мереж і як наслідок відсутністю наразі науково визнаних та експериментально перевірених цілісних і ефективних інноваційних систем навчання й виховання, які підміняються часто несумісними фрагментами з відмінних освітніх систем. Суттєвим недоліком сьогодення вважаємо також неувагу педагогічної науки до побудови інноваційних систем освіти на основі історичного зарубіжного й вітчизняного досвіду і сучасних досягнень інформаційного суспільства.

Аналіз актуальних досліджень. Учені І. Зязюн Б. КоротяєВ, В. Лозова, О. Савченко та інші виявили, що інноваційний педагогічний процес реалізується через застосування таких освітніх концепцій і технологій, як проблемне, дослідницьке, проектне навчання, ділові та організаційнодіяльнісні ігри, технології колективної творчої праці тощо. В останні десятиліття (кінець XX - початок XXI століття) низка зарубіжних і вітчизняних науковців та освітян зосереджені не тільки на вивченні, але й модернізації і впровадженні у практику концепцій і технологій евристичної освіти (від грец. heurisko - знаходжу, відкриваю), яка, на думку вчених, найбільше відповідає інноваційним перетворенням освітнього процесу і спрямована передусім на пізнавально-творчий і професійно-творчий розвиток, самовдосконалення, самореалізацію учасників освітнього процесу.

у дослідженнях вітчизняних науковців (Б. Коротяєв, А. Король, О. Кривонос, М. Лазарєв, І. Проценко, Л. Рибалко, О. Савченко, Л. Сірик, А. Хуторськой) виявлено й узагальнено основні переваги евристичної освіти: пізнавально-творчий і професійно-творчий характер, опора на навчальний діалог, їі людиноцентрованість і спрямованість на творчу самореалізацію сутнісних сил особистості, розвиток пізнавально-творчої самостійності учнів і студентів, успішне освоєння ними сучасних способів діалогової взаємодії, інших евристичних навчальних компетентностей.

Проведені дослідження (Б. КоротяєВ, В. Лозова, А. Хуторськой та ін.) довели, що евристика як основа продуктивної, інноваційної освіти має на сьогодні багатогранний смисл, це наука, що вивчає різні види творчої діяльності; сукупність логічних прийомів, методичних правил і шляхів відшукання істини; метод навчання, який сприяє розвиткові винахідливості, активності, оригінальності мислення.

Разом із тим, наразі не вистачає наукових розвідок, де би було систематизовано з позицій історико-педагогічної науки витоки евристики й евристичної освіти, шляхи їі становлення й розвитку в різні історичні епохи, 
сучасний стан і проблеми подальшого вдосконалення як теоретичних основ, так і технологій освіти евристичного спрямування, змісту та результату.

Тому мета статті - здійснити критичний огляд та узагальнення досліджень вітчизняних науковців, спрямованих на виявлення основних джерел, тенденцій i проблем становлення концепцій i технологій інноваційної евристичної освіти в зарубіжній і вітчизняній педагогічній науці.

Методи дослідження: аналіз, порівняння, узагальнення, систематизація, історико-генетичний, парадигмальний методи для з'ясування особливостей застосування різних технологій в евристичній освіті.

Виклад основного матеріалу. Зародженням евристичної освіти, їі найпершим джерелом учені вважають ідеї та методи навчання Сократа. Характерно, що розкриваючи провідну сутність і зміст нової евристичної педагогіки відомого грецького філософа, різні автори ставлять неоднакові наголоси, виокремлюючи ії провідні особливості. Частина дослідників сократівської евристики навчання, які вивчали цю проблему ще в 60-80 рр. минулого століття (С. Гончаренко, І.Зязюн, В. Онищук, В. Паламарчук, Н. Тарасевич) наголошували на тому, що головне у відкритті Сократа - це нова філософія і педагогіка пізнавального процесу, що спирається на творчий діалог наставника й учнів, базис якого становить єдність основних і навідних запитань, дотичних об'єкта пізнання, що поступово приводить до самостійних висновків самих учнів. Науковці іншої групи (А. Король, Л. Крівшенко, М. Лазарєв, В. Лозова, А. Хуторськой та ін.), які досліджували спадщину Сократа вже у 80-90-х рр. XX і на початку XXI ст., вбачають основу, стрижень сократівської евристичної педагогіки в самостійному виявленні учнями за допомогою наставника насамперед поля незнаного (об'єкта, предмета незнання, недостатність знань про нього, незрозумілість загальноприйнятих тверджень тощо), а потім поступове знаходження розв'язання окресленої проблеми в спільному пошуку за допомогою серії запитань і заміни незнаного знаним, неповного знання більш повним.

Порівнюючи виокремлені нами підходи до сутності одного 3 першоджерел евристичного навчання, ми схильні відзначити не їх протилежність чи альтернативність, а взаємодоповнюваність двох поглядів на одне складне й неоднозначне явище. 3 одного боку, сократівський діалог - пошук істини шляхом складної взаємодії двох суб'єктів - учителя й учнів, а, з іншого, - такий пошук уможливлює тільки досконале та зрозуміле учням з'ясування актуального для них незнаного, яке можна замінити новим знанням тільки в процесі спільних діалогових зусиль. Інтеграція означених підходів до першоджерел нової дидактики, на думку дослідників (А. Хуторськой, Б. Коротяєв, А. Король, М. Лазарєв, О. Нефедченко), і стало початком розвитку теорії евристики й евристичної дидактики, основою якої стала пізнавально-творча (евристична) діяльність суб'єктів освіти (Лазарєв, 2016, с. 215-217). 
Через чотири століття після Сократа, у 90-х роках нашої ери, евристичний метод був по-своєму модернізований Марком Фабієм Квінтиліаном, римським оратором і теоретиком ораторського мистецтва. Квінтиліан у своїй праці «Повчання оратору» виступає і як досвідчений ритор, і як педагог, що виводить з теорії навчання риторики загальні принципи навчання.

Окремі дослідження з'ясували, що вже в другій половині XIX ст. англійський педагог Генрі Едуард Армстронг (1848-1937), критикуючи схоластичні методи навчання сучасної йому школи й наслідуючи Сократа, на основі власних пошуків увів у викладання «евристичний метод». За допомогою одержаних практичних результатів він переконував в ефективності методу, що сприяє інтенсивному розвиткові розумових і творчих здібностей учнів. Г. Армстронг виявив, що сутність методу полягає в тому, що учня включають у ситуацію дослідника: замість вислуховування викладу вчителя він сам видобуває факти і робить висновки. Наставнику дістається найголовніше й найскладніше: поступово навчити учнів евристичного методу, і тоді його застосування буде надійно розвивати їхні продуктивні розумові здібності. Однак, судячи з поодиноких досліджень, на сьогодні поки відомо, що Г.Армстронг обмежився вивченням лише дослідницького методу навчання, який і назвав евристичним (Нефедченко, 2019 , с. 45). На нашу думку, перші розвідки педагогічної спадщини одного із засновників евристичного навчання Д. Армстронга, проведені вітчизняними дослідниками, - це лише перші кроки вивчення вагомих теоретичних i методичних напрацювань знаменитого вченого. Тому на сьогодні потрібні системні зусилля науковців, щоб реально виявити вартості педагогічної спадщини Г.Армстронга та інших учених, які започаткували навчання евристичного гатунку, оцінити їхній внесок у концепції і технології інноваційної освіти.

У контексті даної розвідки заслуговують на увагу педагогічні ідеї нашого національного генія Григорія Савича Сковороди (1722-1794) і видатного вітчизняного педагога Костянтина Дмитровича Ушинського (1824-1870), які заклали основи демократичної й гуманістичної педагогіки, поставили в центр навчально-виховної роботи школи самостійну - творчу і «сродну» - працю учнів.

Вітчизняні науковці (В. Лозова, О. Лазарєва, О. Нефедченко, О. Попова, А. Хуторськой) дослідили концептуальні та технологічні засади евристичного навчання визначного вітчизняного вченого педагога Петра Федоровича Каптерєва (1849-1922), який уперше для освітян другої половини XIX століття розкрив на теоретичному й методичному рівнях сутність форм і методів евристичного навчання. Відзначимо, що саме ця частина педагогічної спадщини П. Каптерєва довгий час (до 90-х років XX столітя) залишалася невідомою для багатьох педагогів і освітян. У проведених дослідженнях 
з'ясовано, що П. Каптерєв уже в 70-90-х рр. XIX століття розробляв теоретичні й технологічні основи евристичного навчання, закладені Сократом, i розглядав їх як один із найважливіших компонентів навчального процесу середньої школи і підготовки майбутніх педагогів.

у дослідженнях новітньої вітчизняної історії інноваційної освіти (Лазарєв та Лазарєва, 2018, 53-59; Лазарєв та Нефедченко, 2018, 84-91; Нефедченко, 2019, с. 39-60; Лазарєв та Козлова, 2019, с. 81-100) можна відзначити виокремлення й розробку основних етапів становлення евристичної освіти та її технологій кінця XX - початку XXI століття, а також розкриття змісту й тенденцій розвитку евристичної освіти під впливом певних соціальних та освітніх факторів.

I етапом становлення евристичної освіти, іï теоретичних i технологічних основ визначено 60-70-ті pp. XX століття. На думку науковців, саме в ці роки в педагогічній науці України започатковуються й закріплюються на основі відродженої уваги до сократівського діалогу, до гуманістичних ідей вітчизняної педагогіки ідеї і технології творчого, неформального та гуманістичного співробітництва учителя й учнів, викладача і студентів. Особливо яскраво це відображено в педагогічній творчості В. Сухомлинського, І. Іванова, В. Шаталова, Б. Коротяєва.

II етап охоплює кінець 70-х - 80-ті рр. XX століття. Для нього, на думку дослідників, характерними стали подальший розвиток ідей навчального діалогу, діалогічної співпраці, освоєння та впровадження в освітню діяльність нових ідей і технологій педагогічної майстерності, дотичні, насамперед, підготовки майбутнього педагога нової формації майстра і гуманіста. Означений етап становлення інноваційної евристичної освіти, на думку дослідників, пов'язаний, передусім, зі становленням і продуктивною працею наукових шкіл академіка АПН України І. Зязюна і професора Н. Тарасевич (Полтавський державний педагогічний інститут імені В.Г. Короленка), професора Б. Коротяєва (Слов'янський державний педагогічний інститут) і професора В. Лозової (Харківський державний педагогічний інститут імені Г.С. Сковороди).

III етап (90-ті рр. XX - перше 10-тя XXI ст.) - це завершення методологічних, теоретичних і технологічних основ евристичних i проблемно-евристичних концепцій і технологій у національній освіті, їх упровадження в практику практику закладів середньої і вищої освіти, зокрема, для професійної підготовки вчителя - творця і майстра (наукові школи Н.Гузій, І. Зязюна і Н. Тарасевич, Б. Коротяєва, В. Лозової, М. Лазарєва). Цей період розвитку евристичної освіти характеризується також розробкою і впровадженням принципово нових креативних концепцій і технологій університетської підготовки докторів філософії (наукові школи професорів А. Сбруєвої, О. Антонової, О. Дубасенюк). 
Початок формування в Україні основних ідей і технологій евристичної освіти в 60-70-х рр. XX ст. дослідники не без підстав пов'язують, насамперед, із діяльністю видатного українського педагога В. Сухомлинського (1918-1970), його інноваційними методологічними, теоретичними і методичними підходами до виховання й навчання школярів, які по суті були альтернативними офіційній педагогіці й освіті радянської школи. Дослідники (Лозова, 2003, с. 13-15; Лазарєва, 2013, с. 69-111; Нефедченко, 2019), зосереджують увагу на тому, що В.Сухомлинський в аспекті інноваційної перебудови існуючої освіти особливу увагу приділяв головному в навчанні й вихованні - організації педагогом самостійної діяльності учнів, особливо діяльності творчого характеру, розглядаючи ії як провідний компонент виховання та розвитку школярів. «Роль учителя, на думку В. Сухомлинського, не давати готові знання, а навчити дітей добувати їх самостійно: аналізувати, досліджувати, виявляти, синтезувати, виокремлювати головне, робити висновки. Видатний педагог вважав, що самостійна праця думки учня $\epsilon$ незамінною умовою розвитку його розуму, пам'яті, кращих рис характеру» (процитовано в Нефедченко, 2019, с. 47). «Радість відкриття, здивування перед істиною, здобутою власними силами, дає людині самоутвердження, переживання гордості, поваги до самої себе» (Сухомлинський, 1977, т. 3, с. 401).

Вивчені нами праці українських науковців (І.Зязюн, В. Лозова, О. Савченко, Л. Крівшенко, О. Лазарєва, О. Нефедченко, Н. Тарасевич та ін.), які досліджували педагогічну спадщину В. Сухомлинського, дають підстави говорити про значну роботу 3 наукового аналізу, систематизації й узагальнення ідей і технологічних побудов В. Сухомлинського, які до цього не стали предметом досліджень у сучасній педагогіці. Особливо це стосується ідей Сухомлинського, які насправді стали теоретичним і методичним фундаментом проблемного й евристичного навчання, що в ті часи в Україні тільки зароджувалось.

Насамперед, це вже зазначені ідеї В. Сухомлинського про самостійні роботи школярів творчого характеру, які вчитель-дослідник розглядав як основу будь-якого навчання й організації освіти взагалі. Важливою вважаємо знайдену науковцями у В. Сухомлинського тенденцію розвитку навчання як творчої праці: з кожним роком обсяг самостійних робіт творчого характеру для школярів повинен збільшуватися для розвитку найкращих творчих розумових здібностей. Учителю при цьому треба використовувати різноманітні методи і прийоми організації розумової праці учнів на уроках і вдома. «Якщо дитина не вчиться мислити і творити словом у початковій школі, то починати цю найтоншу справу в п'ятому класі безглуздо. Уся система навчання й розумового розвитку в нинішній школі потребує докорінного наукового вдосконалення. Нехай у школі панують яскрава думка, живе слово і творчість дитини. На цих трьох китах повинен стояти весь зміст, весь характер духовного життя, розумового 
розвитку школярів» (Сухомлинський, 1977, т. 5, с. 342-343). Такі переконання видатного вітчизняного педагога-гуманіста і творця нової освіти стали реальними принципами евристичної освіти i, як свідчать наукові розвідки, втілюються в життя багатьма кращими педагогами.

Визначальним для побудови сутнісних підвалин евристичного навчання стали постійні настанови Сухомлинського про те, «щоб мету, яку треба досягти у викладанні предмета, ставив не тільки педагог, а й самі учні» (Сухомлинський, 1977, т. 2, с. 107).

Проведені дослідження праць В. Сухомлинського засвідчили увагу вченого до необхідності постійного застосування в самостійній роботі дослідницького методу, щоб не давати учневі готових висновків і доказів істини. Варто також відзначити, що теоретики евристичного навчання скористались виплеканими багаторічними роздумами й досвідом положеннями В.Сухомлинського про те, що самостійна творча і дослідницька робота учнів має бути на всіх етапах уроку, особливо під час вивчення нового матеріалу, а також на етапі осмислення й узагальнення теми в цілому. Кожний учень, на думку В. Сухомлинського, має право вибору серед різних за складністю завдань для самостійної роботи. «Діти дуже чутливі до цієї свободи вибору, вони вбачають у ній можливість утвердити свою гідність...» (Сухомлинський, 1977, т. 4, с. 164).

Таким чином, можна погодитись з думкою науковців про те, що В. Сухомлинський заклав основи сучасної демократичної національної освіти, особистісно орієнтованої та евристичної за своєю метою, змістом і способами діяльності вчителя й учнів, яка базується на пріоритетах самостійної пізнавально-творчої і дослідницької роботи суб'єктів освіти, вільному виборі видів і варіантів завдань, спрямованістю на створення власних, значимих для дітей освітніх продуктів (Лазарєва, 2013, с. 69-111).

Відомий і найбільш досвідчений сучасний вітчизняний учений, педагог-новатор Борис Іванович Коротяєв (1929 р. народження) першим у вітчизняній педагогіці розробив цілісну теорію навчання як творчого процесу. «Творче начало в діяльності вчителя й учнів, можливо, і $є$ тим необхідним, що спроможне дійсно розкрити внутрішні резерви навчання, революціонізувати весь навчально-виховний процес у школі й вивести практику на якісно нові кінцеві результати» (Коротяев, 2006, с. 4). Автор розглядає творчий процес як учнів і студентів, так і їх педагогів-наставників як «самостійний пошук і створення чи конструювання якогось нового продукту (в індивідуальному досвіді учня - нового, невідомого для нього наукового знання або методу, але відомого, як правило, у суспільному досвіді)» (Коротяев, 2006, с. 4). Основою наукової системи Б. Коротяєва, яка була випробувана у власній багаторічній практиці, можна вважати наступні компоненти навчальної діяльності, що допомагають учню і студенту самостійно і творчо підійти до їх освітнього процесу - добування, 
закріплення й використання нових знань сприяють їх самозростанню та самореалізації як особистості. Творче пізнання починається, на думку Б. Коротяєва, з опису предметів, подій, явищ, зв'язків, взаємозалежностей. Далі йде пояснення причин взаємозв'зків і мінливості пізнавальних об'єктів, а потім - передбачення результатів освоєння знань та умінь. Кінцевим кроком можна вважати конструювання конкретного застосування знань під час створення власних освітніх продуктів та їх реалізації у життєвій практиці. Слід зазначити, що Б.І. Коротяєв вважає кінцевим результатом навчальної діяльності не тільки створення учнями і студентами абсолютно нового продукту (креативний рівень), а й моделювання його з уже існуючих, засвоєних елементів (рівень перетворювальний). Результати навчальної діяльності мають оцінюватися з позиції витрат усіх сил - духовних, моральних, фізичних (Коротяев, 2006, с. 159).

Саме використовуючи таку концепцію творчості як основу навчання і виховання, сучасні розробники евристичної освіти (В. Беспалько, Н. Громова, А. Король, О. Кривонос, В. Кумарін, М. Лазарєв, Т. Плохута та ін.) виокремлюють різні рівні евристичної діяльності в освітньому процесі від пояснювальної та інтерпретуючої до конструктивної і креативної (Лазарєв, 2016).

До представників другого і частково третього етапу становлення технологій проблемно-евристичної та евристичної освіти XX століття, на думку українських дослідників, можна віднести полтавську наукову школу академіка, професора, доктора філософських наук Івана Андрійовича Зязюна (1938-2014) і харківську школу доктора педагогічних наук, професора Валентину Іванівну Лозову та ії наукову школу 3 Харківського педагогічного університету.

Визначний філософ, педагог, організатор освіти та науки І.А. Зязюн за підтримки великої громади педагогів-однодумців запровадив фундаментальний науково-дослідний експеримент з підготовки вчителя нового для тих часів типу - самостійної, відповідальної і творчої особистості (Нефедченко, 2019, с. 49).

Проведений системний і структурно-функціональний аналіз професійної підготовки вчителя-майстра у Полтавському педінституті дозволив дослідникам «виокремити з позицій евристичних ідей освіти вирішальні складові інноваційного підходу, до яких ми віднесли формування в зазначеній науковій школі професійно-творчих якостей майбутнього вчителя із застосуванням проблемних та евристичних технологій:

а) формування педагогічного артистизму - мотивів і вмінь для створення і збереження, по-перше, творчого самопочуття майбутнього вчителя, а, по-друге, перетворення традиційного навчального процесу в цілісне драматичне дійство за всіма принципами, законами та технологіями театральної педагогіки; 
б) формування знань, здібностей, умінь і цінностей професійного спілкування як гуманістичної, конструктивної і творчої діяльності, володіння творчим діалогом, діалоговою взаємодією на уроках, у виховних справах, евристичних бесідах, дискусіях, іграх, змаганнях тощо;

в) формування в усіх студентів достатнього рівня риторичної майстерності і культури педагогічної дії (аналогічно до дії сценічної);

г) становлення мотивів, здібностей, умінь до створення і реалізації творчих освітніх продуктів.

У цій, хоч і лаконічній та вельми узагальненій формі, можна знайти провідні інноваційні спрямування наукової школи І. Зязюна і Н. Тарасевич: навчати досконалого професійного діалогу, володіння основними професійно-творчими вміннями та конкретними методами спільної 3 учнями діяльності, обов'язково й систематично формувати невиправдано забуту в сучасних реаліях риторичну культуру майбутнього педагога.

До II та III етапів розвитку концепцій і технологій евристичної освіти можна віднести, як раніше відзначено, надзвичайно продуктивну науковопедагогічну діяльність професора Харківського національного педагогічного університету ім. Г. С. Сковороди В. Лозову та ії наукову школу, у якій уперше у вітчизняній педагогіці багатоаспектно досліджено проблему активізації пізнавальної діяльності учнів і студентів в умовах проблемного й евристичного навчання. В.Лозова не протиставляє в освітньому процесі проблемні та евристичні методи і технології навчання (як це робить, зокрема, проф. А. Хуторськой), а вважає за необхідне їх діалектично поєднувати, не нехтуючи при цьому лекційнодемонстраційними методами. Провідна ж педагогічна мета при цьому викладача і вчителя, на думку В. І. Лозової, - створити необхідні умови для успішної самореалізації основних пізнавально-творчих здібностей, умінь, особистих цінностей школярів і студентів. Науковці означеної школи, включаючи ії керівника, вважають сформовану ними на сьогодні теорію творчої самореалізації особистості методологічною основою освітнього процесу взагалі й застосування проблемних та евристичних освітніх технологій зокрема. Слід зауважити, що під керівництвом В. Лозової викладачами й аспірантами (Л. Калашникова, О.Кондратюк, Д. Попов, О. Попова, Л. Рибалко, К. Лазарєва та ін.) розроблені, випробувані й захищені цілісні, багатоструктурні технології не тільки освоєння студентами й учнями нових моделей евристичного діалогу та евристичної бесіди в різних компонентах навчального процесу, але й технології навчання учнів запитальної діяльності (умінь ставити комплекс запитань описових, пояснювальних, прескриптивних тощо), технологій професійної самореалізації з використанням евристичних та акмеологічних методів самовдосконалення; технологій поступового переходу до використання конструктивних і креативних методів професійної діяльності. 
Узагальнення основних напрямів роботи наукової школи В. Лозової дозволив у короткому вигляді представити частину результатів діяльності означеної школи.

Самореалізація творчого потенціалу особистості, зокрема, майбутнього вчителя. Дослідниками наукової школи (В. Лозова, Л. Левченко, Л. Рибалко, І. Іонова) було виявлено нові сутнісні характеристики професійнотворчої самореалізації майбутнього вчителя - здатність до самоформування професійно-творчого потенціалу, бажання і спроможність досягти особистісної вершини-акме у процесі опанування основами педагогічної діяльності в різних ії видах - виховній, навчально-пізнавальній, дослідницькій, самоосвітній. Віднайдено нові технології на мотиваційному, формувальному й діагностичному етапах професійної самореалізації.

Цілісне та системне формування пізнавальної активності суб'єктів освіти. В.Лозова та представники ії наукової школи вважають, що систематичне включення студентів та учнів у постановку і розв'язання проблемних і евристичних задач з використанням діалогової взаємодії поступово обмежує обсяг репродуктивної роботи й нарощує обсяг конструктивної і креативної праці, що інтенсивно формує необхідні пізнавально-творчі та професійні якості - ініціативність, самостійність, оригінальність у здобутті результатів, у переносі знань та вмінь у нову ситуацію, у виявленні нової проблеми (Лозова, 2000).

Технології діалогізації освітнього процесу: а) технології навчання ставити систему пізнавальних запитань; б) технології розв'язання складних педагогічних ситуацій; в) технології самостійного вибору адекватної громадянської позиції; г) технології креативного самопроєктування й самоорганізації діяльності майбутнього вчителя в реальних освітніх ситуаціях тощо.

Професор Сумського державного педагогічного університету імені А. С. Макаренка Микола Остапович Лазарєв у 1993 році очолив кафедру педагогічної творчості і в співдружності зі своїми соратникамивикладачами й аспірантами створив систему підготовки сучасного вчителя на базі освоєння й застосування концепцій і технологій педагогічної творчості. Пізніше (у 2000-ні рр.) на основі авторської концепції пізнавально-творчої і професійно-творчої самореалізації розроблено авторський варіант евристичної освіти з різнорівневими видами евристичної освітньої діяльності - аналітично-пошукової, перетворювальної, конструктивної та креативної. Мета - сформованість у майбутнього педагога необхідних професійно-творчих компетентностей та їх самореалізація у практичній фаховій діяльності.

Евристичну освіту та її складову - евристичне навчання - вперше розглядають у науковій школі проф. М.Лазарєва в системі різних методологічних позицій і підходів: 
а) у загальнометодологічному аспекті - як цілісну, нелінійну й нерівноважну система освітньої діяльності, стратегія якої спрямована на самореалізацію творчого потенціалу особистості, спроможної створювати особистісно й соціально значимі освітні продукти;

б) в історико-педагогічному аспекті - як новий і прогресивний феномен розвитку теорії і практики педагогічної науки, у змісті і структурі якого збережено та вдосконалено раніше здобуті надбання сократівсько-діалогічного, проблемного, проектного, інтерактивного навчання - і стверджуються пріоритети конструктивної й креативної діяльності освітніх суб'єктів;

в) у процесуально-технологічному аспекті - як динамічна єдність мотиваційно-цільового, проектного, виконавського, корекційного і рефлексивно-діагностичного компонентів діяльності освітніх суб'єктів, що включає різні за складністю види освітньої й наукової праці (Лазарєв та Нефедченко, 2018).

Педагоги-новатори даної наукової школи вперше застосували інноваційне евристично-модульне навчання на теоретичному, експериментальному і методичному рівнях. Дослідники розробили та успішно випробували інноваційні технології евристичної освіти, зокрема такі:

- лекція прямої дії;

- технологія навчання i застосування профессійного й гуманістичного діалогу;

- семінарські $і$ практичні заняття як презентації та аргументований захист самостійно створених освітніх продуктів конструктивного або креативного характеру (теоретична доповідь, твір, розробка навчального модуля, освітній проект, підготовлені статті, моделі невеликого за обсягом науково-дослідного експерименту тощо);

- педагогічна практика як система проектно-дослідницьких студій учителів-майстрів і студентів (Лазарєв та Лазарєва, 2018).

Новітнім напрямом розвитку ідей і технологій інноваційної освіти у вищій школі, і за часом, і за метою, стало реформування докторської підготовки (підготовки докторів філософії PhD), що охоплює весь європейський простір вищої освіти (ЄПВО). Дослідники відзначають два основні суспільні чинники цього нового процесу: зовнішні (розвиток суспільства знань, у якому здобуте шляхом наукових досліджень нове знання перетворюється у провідну рушійну силу розвитку суспільства) і внутрішні (перетворення в Україні докторської підготовки на третій цикл вищої освіти у контексті Болонського процесу). Завдяки таким чинникам докторська підготовка набуває статусу докторського циклу вищої освіти і зазнає в межах ЄПВО системних трансформацій, що стосуються всіх ії складових - мети, завдань підготовки PhD, структури, форм, технологій реалізації, критерій якості результатів тощо (Сбруєва, 2019, с. 184). 
Узагальнюючи перший досвід підготовки PhD, можемо відзначити такі аспекти діяльності, які активно здійснюються в нашій науковій школі.

1. Створення по відношенню до молодого науковця дружньої екосистеми з глибинною повагою до особистості і спокійною, але послідовною вимогливістю. Таке ставлення, як показав досвід, може життєтворно формуватися у постійному спілкуванні, гуманному і предметному діалозі, часто сам-на-сам, коли виявляються потреби, нерозв'язані проблеми, страхи перед невідомим і загрозливим.

2. Дотримання Європейського кодексу дослідницької доброчесності в нас провадиться сполученням двох чинників: по-перше, строгим, 3 використанням сучасних інформаційних засобів попередженням плагіату на матеріалі окремих фрагментів дисертації і наукових публікацій, а, по-друге, роботи з науковцями з оволодіння методами досягнення самостійності й оригінальності наукового тексту. Практика доводить, що така інтеграція із виявленням і досягненням у результаті неодноразової переробки достатніх ознак оригінальності форми та змісту наукової думки, їі писемної культури і переконливості не тільки попереджає наукову недоброчесність, але й продуктивно впливає на особистісну наукову самореалізацію.

3. Систематичний тренінг з оволодіння науковими методами дослідження та широке впровадження на наукових семінарах персонального захисту окремих фрагментів дисертаційного дослідження (з назвами й використанням методологічних підходів, використанням різних методів і технологій) із застосуванням коректного наукового діалогу i дружньої предметної дискусії.

Сучасна докторська підготовка, якщо узагальнити вітчизняний і зарубіжний досвід, без усяких сумнівів користується послугами народженої у XX столітті креативної педагогіки, чергового етапу розвитку інноваційної, зокрема, евристичної чи евристично-проблемної освіти, тобто цілком базується на благородній, життєствержувальній і одночасно прагматичній парадигмі - створити дійсно новий, значимий для людей і суспільства науковий продукт - суттєвий чинник для побудови фрагменту більш зручного і більш прийнятного життя.

Висновки та перспективи подальших наукових розвідок. Таким чином, з одного боку, евристична освіта $€$ одним із найдавніших видів навчання, заснованого на сократичній бесіді або евристичному евристичному діалозі. 3 іншого боку, реалізація в освітній практиці технологій евристичної освіти являє собою в різні епохи результат педагогічних зусиль прогресивних дослідників-педагогів, які виступали й виступають проти засилля традиційних передавальних, антидіалогічних методів і форм навчання. У зв'язку з цим актуальність технологій евристичного навчання та їх подальшого розвитку обґрунтовується об'єктивними вимогами суспільства до освітнього процесу і виховними 
завданнями, що пов'язані з формуванням самостійної, творчої, конкурентоздатної особистості.

Тривала історія розвитку навчально-виховних практик свідчить, що забезпечити сформованість в учнів і студентів необхідних евристичних здібностей можливо через їхню включеність у різні види евристичної діяльності - пошукової, реконструктивної, конструктивної, креативної. Це, у свою чергу, забезпечує розвиток розумових процесів підростаючої особистості, активізацію ії творчого мислення і продуктивної діяльності. На сучасному етапі модернізації української освіти саме евристична освіта, їі інноваційні концепції і технології допоможуть досягнути головної мети сьогодення виховати гуманістичну, гармонійно розвинену особистість, здатну до самозростання, самовдосконалення, самореалізації творчого потенціалу.

3'ясовано актуальні проблеми інноваційної, зокрема евристичної, освіти професіоналів, які вимагають невідкладного розв'язання: дефіцит навчальних, наукових та матеріальних ресурсів, нерозвиненість менеджменту сучасних інноваційних освітніх і наукових проектів, відсутність у країні ефективних науково-освітніх мереж, які б об'єднували ресурси вищої і середньої освіти), що й стануть предметом подальших наукових розвідок.

\section{ЛІТЕРАТУРА}

Гузій, Н. В. (2013). Проблемно-евристична спрямованість методичного арсеналу дидаскалогічної підготовки. Професійно-творча самореалізація майбутнього педагога в інноваційній освіті, 10-27 (Huzii, N. V. (2013). Problem-heuristic orientation of the methodological arsenal of didactological training. Professionalcreative self-realization of the future teacher in innovative education, 10-27).

Каптерев, П. Ф. (1990). Эвристическая форма обучения в народной школе. Антология педагогчческой мысли России второй половины XIX - начала XX в. Москва (Kapterev, P. F. (1990). Heuristic form of education in a public school. Anthology of Russian pedagogical thought in the second half of the 19th - beginning of the 20th centuries. M oscow).

Коротяев, Б. И. (2006). Учение - процесс творческий. Т. 2. Луганск: Альмаматер (Korotiaiev, B. I. (2006). Learning is a creative process. Luhansk: Alma Mater).

Кривонос, О. (2010). Профресійно-творчі вміння педагога та шляхи їх формування (Kryvonos, 0. (2010). Teacher's professional and creative skills and ways of their formation).

Лазарєв, М. О. (2016). Педагогічна творчість. Суми (Lazariev, M. О. (2016). Pepagogical creativity. Sumy).

Лазарєв, М. О., Козлова, О. Г., Крижко, В. В. (2019). Особливості професійно-творчої самореалізації майбутнього педагога у персоналізованій евристичній освіті. Пізнавально-творча і професійна самореалізація особистості в евристичній ocвimi, (cc. 81-100). Суми (Lazariev, М. O., Kozlova, O. H., Kryzhko, V. V. (2019). Features of professional and creative self-realization of the future teacher in personalized heuristic education. In M. O. Lazarev, O. H. Kozlova (Eds.), Cognitivecreative and professional self-realization of the personality in heuristic education, (pp.81-100). Sumy).

Лазарєв, М., Лазарєва, О. (2018). Особливості і компоненти евристичної освіти у професійній підготовці майбутнього педагога. Науковий часопис НПУ імені М.П. 
Драгоманова. Серія 16. Творча особистість учителя: проблеми теорії і практики, 30 (40), 53-59 (Lazariev, M., Lazarieva. O. (2018). Features and components of heuristic education in the future teacher's professional training. Scientific journal of NPU named after M. P. Drahomanov, Series 16. The creative personality of the teacher: problems of theory and practice, 30 (40), 53-59).

Лазарєв, М., Нефедченко, О. (2018). Професійна підготовка майбутнього педагога в контексті сучасної евристичної освіти. Науковий часопис НПу ім. М. П. Драгоманова. Серія 16 Творча особистість учителя: проблеми теорії $i$ практики, 31 (41), 84-91 (Lazariev, M., Nefedchenko, 0. (2018). Professional training of the future teacher in the context of modern heuristic education. Scientific journal of NPU named after M. P. Drahomanov, Series 16 . The creative personality of the teacher: problems of theory and practice, 31 (41), 84-91).

Лозова, В. (2003). Інноваційна дидактика В. О. Сухомлинського. Наукові записки Кіровоградського ДПУ ім. В. Винниченка. Сер. Педагогічні науки, 52 (1), 13-15 (Lozova, V. (2003). Innovative didactics of V.O. Sukhomlynskyi. Scientific notes of Kirovohrad State University named after V. Vinnychenko. Series Pedagogical Sciences, 52 (1), 13-15).

Лозова, В. І. (2000). Цілісний підхід до формування пізнавальної активності школярів. Белгород (Lozova, V. I. (2000). A holistic approach to the formation of cognitive activity of students. Belgorod).

Нефедченко, О. (2019). Розвиток концепцій і технологій евристичної освіти у зарубіжній і вітчизняній педагогічній науці. Пізнавально-творча $i$ професійна самореалізація особистості в евристичній освіті, (сс. 39-60). Суми (Nefedchenko, 0. (2019). Development of concepts and techniques of heuristic education in foreign and national pedagogical science. In M. O. Lazarev, O. H. Kozlova (Eds.), Cognitive-creative and professional self-realization of personality in heuristic education, (pp.39-60). Sumy).

Лазарєва, О. (2013). Самостійна творча діяльність як провідний чинник самореалізації креативного потенціалу особистості. Професійно-творча самореалізація майбутнього педагога в інноваційній освіті, (сс. 69-111). Суми (Lazarieva, 0. (2013). Independent creative activity as a leading factor in the self-realization of the creative potential of the individual. In M. O Lazarev (Ed.), Professional-creative selfrealization of the future teacher in innovative education, (pp.69-111). Sumy).

Зязюн, І. А. (Ред.) (1997). Педагогічна майстерність. Київ: Вища школа (Ziaziun, І. А. (Ed.) (1997). Pedagogical Skill. Kyiv: Higher School).

Зязюн, І. А. (Ред.) (2008). Педагогічна майстерність. Київ: СПД Богданова А. М. (Ziaziun, I. A. (Ed.) (2008). Teaching Skills. Kyiv: SPD named after Bordanov A. M .).

Сбруєва, А. (2019). Тенденції реформування докторської підготовки у європейському просторі вищої освіти: соціальний вимір змін). Освіта для XXI століття: виклики, проблеми, перспективи: матеріали I Міжнародної науково-практичної конферениії. Том 1. Суми, 2019, (сс. 184-188) (Sbruieva, А. (2019). Trends in reforming doctoral training in the European space of higher education: the social dimension of change). Education for the XXI century: challenges, problems, prospects: materials of the I International scientific-practical conference. Vol. 1. Sumy, 2019, (pp. 184-188)).

Сковорода, Григорій (1961). Твори у 2 томах. Київ: АН УРСР, Т. 1, (сc. 324, 327) (Skovoroda, Hryhorii (1961). Works in 2 volumes. Kyiv: AN URSR, vol. 1, (pp. 324, 327)).

Сухомлинський, В. О. (1977). На трьох китах. Вибрані твори в п'яти томах. К.: Рад. школа. Т. 5. (сс. 339-343) (Sukhomlynskyi, V. O. (1977). On three whales. Selected works in five volumes. K.: Rad. shkola. Vol. 5, (pp. 339-343)). 
Сухомлинський, В. О. (1977). Народження громадянина. Вибрані твори в п'яти томах. К.: Рад. школа, Т. 3. (сс. 283-582) (Sukhomlynskyi, V. О. (1977). Birth of a citizen. Selected works in five volumes. K.: Rad. shkola. Vol. 3, (pp. 283-582)).

Сухомлинський, В. О. (1977). Павлиська середня школа. Вибрані твори в п'яти томах. К.: Рад. школа, Т. 4. (сc. 7-390) (Sukhomlynskyi, V. О. (1977). Pavlysh Secondary School. Selected works in five volumes. K.: Rad. shkola. Vol. 4, (pp. 7-390)).

Сухомлинський, В. О. (1977). Сто порад учителеві. Вибрані твори в п'яти томах. К.: Рад. школа, Т. 2. (сс. 419-654) (Sukhomlynskyi, V. O. (1977). One hundred tips for the teacher. Selected works in five volumes. K.: Rad. shkola. Vol. 2, (pp. 419-654)).

Тарасевич, Н. Н. (1985). Исследование проблемы формирования основ педагогического майстерства у студентов. Пути совершенствования психолого-педагогической підготовки учителя в свете основних направлений реформы общеобразовательной и профессиональной школы. Полтава (Tarasevych, N. N. (1985). The study of the problem of forming the foundations of pedagogical mastery among students. Ways to improve the psychological and pedagogical training of teachers in the light of the main directions of reform of the comprehensive and vocational schools. Poltava).

Тарасевич, Н. М. (2012). Теоретична та навчально-методична розробка педагогічної майстерності - нової галузі у педагогіці, ї̈ впровадження у практику підготовки і підвищення кваліфікації учителів (Tarasevych, N. М. (2012). Theoretical and educational-methodological development of pedagogical mastery - a new branch in pedagogy, its introduction into the practice of teacher training and advanced training).

Lazarev, M., Nefedchenko, 0. (2019). Conceptions and techniques of professional future teacher's training in the pedagogical works of the famous Ukrainian scientist B. I. Korotiaiev. Theory and practice of introducing a competent approach to higher education in Ukraine, (pp. 272-281). Vienna.

Nefedchenko, O. I. (2018). Foreign and native scientists about the ideas and techniques of heuristic education. Science and Education a New Dimension. Pedagogy and Psychology, VI (68), Issue: 164, 41-45.

\section{PEЗЮME}

Сбруева Алина, Бойченко Марина, Чашечникова Ольга. Становление концепций и технологий эвристического образования в исследованиях украинских ученых.

Статья посвящена аналитическому обзору и обобщению результатов исследований украинских ученых, посвященных выявлению основных источников, тенденций и проблем становления концепций и технологий эвристического образования в зарубежной и отечественной педагогической науке. Установлены три основных источника и одновременно три составляющие эвристического образования: сократовский (эвристический) диалог, концепция творческой самореализации личности; методологические и технологические основы творческой деятельности. Выявлено, что эвристическое образование (эО) и его составляющие имеют тенденции к постоянному совершенствованию, модернизации сферы применения и одновременно усложнению содержания и способов освоения и использования.

Ключевые слова: эвристическое образование, концепции и технологии, эвристический диалог, творческая самореализация личности, творческая деятельность, зарубежная и отечественная педагогическая наука, этапы, тенденции развития. 


\section{SUMMARY}

Sonieva Alina, Boichenko Manyna, Chashedmikova Olga. Formation of concepts and techniques of heuristic education in researches of Ukrainian scientists.

The article is devoted to the analytical review and synthesis of the results of Ukrainian scientists' researches, aimed at identifying the main sources, tendencies and problems of the formation of concepts and techniques of heuristic education in foreign and native pedagogical science. Three main sources and simultaneously three components of heuristic education have been identified: Socratic (heuristic) dialogue (its primary source and main specific characteristic); the concept of creative self-realization of the individual as a strategy for the development of democratic and humanistic society and the goal of modern education; methodological and technical foundations of creative activity - the essence of heuristic education. Native scholars have identified: heuristic (Socratic) dialogue as the primary source of heuristic education and its other components tend to constantly improve, modernize, expand the scope and at the same time complicate the content and forms, ways of development and use. This tendency is confirmed by the writings of either the followers of Socrates (Platon, Kvintylian, H. Armstrong, P. Kapteriev, N. Barbalis, P. Freire, M. Bakhtin) or modern scholars. It has been proved that heuristic techniques, in particular heuristic dialogue, make it possible for students to find out the unknown things to them in a perfect and understandable way, which can be replaced by new knowledge only in the process of combined parity, motivated, powerful and competent efforts.

The most recent period of development of heuristic education in the late $X X$ - the first decade of the XXI century, as was revealed by researchers (B. Korotiaiev, N. Huzii, V. Lozova, M. Lazariev, O. Nefedchenko, O. Popova) can be divided into three stages (1960-1980s; 19801990; 2000s-2019) in accordance with the identified tendencies of expansion, improvement and complication of conceptual constructions and techniques of heuristic and problembased-heuristic education. The I stage researchers associate, first of all, with the innovative development of theoretical foundations and teaching techniques as a creative process by prof. B. Korotiaiev and his scientific school. II stage - development of theories of techniques of problem-based and heuristic education on the basis of concepts of personality's creative self-realization (scientific school of professor V. Lozova) and preparation of the personality of the future teacher-master (scientific school of professors I. Ziaziun and N. Tarasevych); III stage - deepening and modernization of heuristic education, development of techniques of constructive and creative activity in training of teachers and doctors of philosophy (scientific schools headed by professors B. Korotiaiev, V. Lozova, N. Huzii, M. Lazariev, A. Sbruieva, 0 . Semenog, 0 . Antonova). Actual problems of innovative, in particular heuristic, education of professionals, which require immediate solution (shortage of educational, scientific and material resources, underdeveloped management of modern innovative educational and scientific projects, lack of effective scientific and educational networks in the country that would combine the resources of higher and secondary education) are found out.

Key words heuristic education, concepts and techniques, heuristic dialogue, creative self-realization of personality, creative activity, foreign and native pedagogical science, stages, tendencies of development. 